\title{
АНАЛІЗ ІНВЕСТИЦІЙНОЇ ПРИВАБЛИВОСТІ СІЛЬСЬКОГОСПОДАРСЬКИХ ПІДПРИЄМСТВ УКРАЇНИ
}

\author{
Назаренко Дар`я Володимирівна \\ слухач магістратури \\ Сумський національний аграрний університет (м.Суми, Україна) \\ ORCID 0000-0002-2935-6719 \\ nazarenk095@ukr.net
}

В статті розглянуто сучасний стан та особливості розвитку інвестиційної привабливості сільськогосподарських підприємств України. Здійснено аналіз іноземних інвестицій в економіку та АПК України. Розкрито основні проблеми інвестиційного забезпечення сільськогосподарських підприємств.

Ключові слова: інвестиції, інвестиційна привабливість, розвиток АПК, інвестиційна діяльність, проблеми розвитку АПК.

DOI: https://doi.org/10.32845/bsnau.2019.2.11

Постановка проблеми у загальному вигляді. Розвиток агропромислового сектору економіки, як і будь-якої іншої галузі, вимагає великих інвестицій. Проблема полягає не лише у застарілій матеріально-технічній основі, а й у потребі нових технологій для підвищення конкурентоспроможності галузі.

Більшість існуючого сільськогосподарського устаткування мають застарілу конструкцію. Агропідприємства потребують введення в експлуатацію сучасної техніки, але грошей на її придбання немає. 3 огляду на поточну платоспроможність, зменшення цього розриву можливе лише за рахунок зниження цін на сільськогосподарську техніку, але це проблематично.

Єдине рішення - підвищення фрінансової спроможності, рівня рентабельності сільськогосподарських підприємств, відповідності амортизаційної політики потребам матеріально-технічної бази.

Ефективний розвиток аграрного сектора в умовах ринку неможливий без активізації інвестиційної діяльності, істотного збільшення обсягів інвестицій, вибору найбільш ефективних джерел фінансування.

Аналіз останніх досліджень та публікацій. Дослідження теорії та практики інвестицій та інвестиційної діяльності було здійснено багатьма вченими. Лібор Кркоська вважає, що прямі іноземні інвестиції (ПІІ) позитивно впливають на країни з перехідною економікою. По-перше, прямі іноземні інвестиції $€$ важливим джерелом фрінансування країн з перехідною економікою, оскільки допомагають покрити дефіцит поточного рахунку, десріцит фіскального бюджету (у випадку пов'язаних з приватизацією ПІІ) та доповнює недостатні внутрішні ресурси для фінансування як зміни власності, так і формування капіталу. По-друге, порівняно з іншими варіантами фінансування, ПІІ також полегшує передачу технологій, новацій та навичок, а також допомагає місцевим підприємствам розширюватися на зовнішні ринки [1].

Однак загальне сприйняття з точки зору інвестицій полягає в тому, що операційна прибутковість багатьох сільськогосподарських підприємств є досить мінливою і підлягає ряду неконтрольованих факторів, таких як ціни на сировину та погоду.

С. Гуткевич та О. Захарчук зазначають, що іноземний капітал у фрормі інвестицій надходить насамперед у ті країни, які мають стабільну та ефективну правову базу щодо режимів залучення та використання іноземних інвестицій [2;3].
На думку М. Кисіля, М. Коденської та П. Саблук, основними причинами інвестиційних проблем в аграрному секторі $€$ міжгалузеві дисбаланси в економіці внаслідок невідповідності цін на ресурси та сільськогосподарську продукцію, відсутність компенсацій, скорочення державних інвестицій у виробництво сільського господарства та вплив інших ринкових механізмів $[4 ; 5]$.

На думку В. Гераймовича, Ю. Лупенка, та В. МеселяВеселяка, до основних факторів, що перешкоджають притоку інвестицій у сільське господарство, належать непослідовна та хибна інвестиційна політика держави, недорозвиненість фінансових ринків, несприятливі умови для розвитку малого бізнесу в сільській місцевості, низька ліквідність інвестицій, низька прибутковість капіталу сільськогосподарських підприємств, відсутність ринку землі [6;7].

Т. Ратошнюк, М. Мартинюк вважають інвестиції в сільськогосподарські підприємства ризикованими [8], інші (ми 3 ними згодні) критикують цю думку [9]. Більшість авторів відзначають високий рівень інвестиційної привабливості таких підприємств; однак є деякі протилежні погляди [10; 11;12].

Основним фактором забезпечення інвестицій у сільськогосподарські підприємства $€$ фінансове забезпечення цього виду економічної діяльності. С. Гуткевич звертає увагу на низку факторів, які впливають на інвестиційні процеси в сільському господарстві, зокрема, економічні та політичні фактори [13]. Інвестиційні потреби сільськогосподарських підприємств є предметом дослідження таких науковців, як П. Гайдуцький, А. Ліссітса та інші.

Однак, незважаючи на багатоаспектність досліджень, деякі питання, пов'язані з особливостями та напрямами посилення та підвищення ефективності інвестицій у сільськогосподарський сектор, залишаються недостатньо вивченими.

Формування цілей статті. Дослідження мають на меті оцінити сучасний стан інвестицій у сільськогосподарські підприємства та вивчити сфери його активізації.

Викладення основного матеріалу дослідження. Для успішного розвитку сільськогосподарських підприємств потрібні масштабні та ефективні інвестиції. Однак зараз позичені кошти і власні джерела сільськогосподарських товаровиробників $€$ недостатніми для задоволення їхніх інвестиційних потреб. Іноземні інвестиції в сільське господарство отримуються в обмеженій кількості, а їх частка в загальних інвестиціях залишається низькою.

Сьогодні міжнародна практика визнає об'єктивну пот- 
ребу у виділенні значних обсягів бюджетних коштів на підтримку розвитку сільського господарства. Лідерами такої підтримки є Швейцарія, Норвегія, Південна Корея та Японія, в яких інвестиційні субсидії в доходах фермерів становлять від 60 до 70 відсотків.

Суть державної інвестиційної політики полягає насамперед у визначенні пріоритетів, джерел та обсягів інвестицій у сільське господарство. Основними його цілями є збільшення капітальних вкладень у ті галузі та сфери діяльності, які сприяють швидкому подоланню кризової ситуації сільського господарства країни. Складність вирішення проблеми розвитку інвестиційних процесів та збільшення інвестицій в основні фонди зумовлена тривалим періодом низькоприбуткового та збиткового виробництва, зокрема виробництва тваринництва, у більшості сільськогосподарських підприємств, що стало головною причиною різкого зниження інвестицій у цю галузь [14].

Інвестиційна привабливість сільськогосподарських підприємств відкриває нові можливості диверсифікації для вітчизняних та іноземних інвесторів, збільшує гарантії для іноземних інвесторів щодо їх участі в інвестиційних проектах. Аналіз інвестиційної привабливості дає можливість виявити слабкі сторони в діяльності компанії та запропонувати заходи щодо їх усунення та створення умов для залучення інвестиційних ресурсів. Це, у свою чергу, дає можливість інвесторам прийняти рішення про вкладення коштів у саме це підприємство. На сьогодні для більшості сільськогосподарських підприємств реальні інвестиції - єдиний напрям для інвестування в них. Тому наше подальше дослідження буде спрямоване на розкриття стану та проблем реальних інвестицій в економіку та сільське господарство України.

В останні роки підтримка економічного розвитку країни була спрямована на залучення іноземних інвестицій. Обсяг іноземних інвестицій в економіку України протягом 2012 2018 років представлений у таблиці 1.

Таблиця 1. Прямі іноземні інвестиції (акціонерний капітал) країн світу в економіку України на 1 січня (наведені країни з найбільшими інвестиціями), млн. дол. США

\begin{tabular}{|l|c|c|c|c|c|c|c|}
\hline \multicolumn{1}{|c|}{ Країна } & 2012 & 2013 & 2014 & 2015 & 2016 & 2017 & 2018 \\
\hline Австрія & 2317,5 & 2476,9 & 2314,0 & 1648,7 & 1559,8 & 1099,9 & 1038,8 \\
\hline Велика Британія & 2536,4 & 2496,9 & 2768,2 & 2153,4 & 1790,3 & 1947,0 & 1944,4 \\
\hline Віргінські острови (Брит.) & 1580,2 & 1888,2 & 2275,9 & 1988,3 & 1715,0 & 1682,3 & 1358,4 \\
\hline Кіпр & 12700,8 & 15907,7 & 17725,6 & 11971,6 & 9894,8 & 8785,5 & 8932,7 \\
\hline Нідерланди & 9323,8 & 8727,6 & 9007,5 & 6887,3 & 6090,3 & 6028,4 & 6395,0 \\
\hline Німеччина & 5329,8 & 4496,3 & 2908,4 & 2110,6 & 1604,9 & 1564,2 & 1682,9 \\
\hline США & 966,6 & 976,5 & 934,7 & 789,1 & 717,2 & 585,2 & 517,4 \\
\hline Франція & 1993,1 & 1510,3 & 1520,5 & 1341,9 & 1299,1 & 615,6 & 723,4 \\
\hline Всього інвестицій з усіх країн & 48197,6 & 51705,3 & 53704,0 & 38356,8 & 32122,5 & 31230,3 & 31606,4 \\
\hline
\end{tabular}

$$
\text { Джерело: [15] }
$$

За останні сім років іноземні інвестиції в економіку України зменшились на 35 відсотків, різкий спад інвестицій припадає на 2014 рік. Це зумовлене економічною та політичною кризами в Україні. Але такі країни як: Кіпр (28,2 відсотка), Нідерланди (20,2 відсотка) продовжують інвестувати в Україну. Більшість інвестицій з різних країн було здійснено у 2013 році та на початку 2014 року становило 53,7 мільярда доларів
США, що порівняно з 2012 роком - це збільшення на 5,5 мільярдів доларів або на 11,4 відсотка. Порівняно з початком 2014 року, наприкінці 2015 року обсяг інвестицій впав на 21,6 мільярда доларів США або на 40 відсотків.

У той же час Україна здійснювала прямі інвестиції в інші країни, обсяг яких за період 2012-2018 рр. майже не змінився і становить 6,2-6,7 млрд. доларів США (табл. 2).

Таблиця 2. Прямі інвестиції (акціонерний капітал) в економіку країн світу з України на 1 січня (наведені країни з найбільшими інвестиціями), млн. дол. США

\begin{tabular}{|l|l|l|l|l|l|l|l|}
\hline \multicolumn{1}{|c|}{ Країна } & \multicolumn{1}{c|}{2012} & \multicolumn{1}{c|}{2013} & \multicolumn{1}{c|}{2014} & \multicolumn{1}{c|}{2015} & \multicolumn{1}{c|}{2016} & \multicolumn{1}{c|}{2017} & \multicolumn{1}{c|}{2018} \\
\hline Латвія & 80,4 & 95,5 & 98,6 & 85,0 & 69,8 & 68,4 & 60,9 \\
\hline Кіпр & 5899,7 & 5917,6 & 5925,1 & 5926,1 & 5923,7 & 5930,5 & 5932,5 \\
\hline Польща & 46,3 & 52,3 & 56,4 & 53,4 & 50,2 & 48,7 & 6,7 \\
\hline Російська Федерація & 236,6 & 292,6 & 377,9 & 196,4 & 122,8 & 144,1 & 150,3 \\
\hline Всього інвестицій з України & 6435,4 & 6568,1 & 6702,9 & 6456,2 & 6315,2 & 6346,3 & 6322,0 \\
\hline
\end{tabular}

\section{Джерело: [15]}

Інвестиції з України в основному спрямовуються на Кіпр. Вони становлять 93,8 відсотка від загальної суми або 5,9 млрд доларів США. Невеликі інвестиції надходять до Російської Федерації, Латвії та інших країн.

Отримані прямі іноземні інвестиції повинні бути спрямовані на інноваційний розвиток усіх галузей економіки в Україні, особливо сільського господарства, оскільки кожен третій долар, який надходить у країну, генерується за рахунок експорту сільськогосподарської продукції, кожен п'ятий українець працює у сільському господарстві та цій галузі робить значний внесок у ВВП.
Прямі іноземні інвестиції у сільське господарство, лісове господарство та рибне господарство в період 2012-2018 pр. у порівнянні з іншими секторами економіки України наведені в таблиці 3.

Іноземні інвестиції зосереджені в основному на розвитку промисловості (на кінець 2012 року - 36 відсотка та 2018 - 33,4 відсотка), а також на переробній промисловості (2012 - 25,7 відсотка та 2018 - 25,3 відсотка). Інвестиції в сільське, лісове та рибне господарство незначні, і наприкінці 2018 року становили лише 1,8 відсотка від загальної суми інвестицій в економіці України.У той же час, у 2018 році, у порівнянні 3 2012 р. вони знизилися з 725,3 до 578,6 млн доларів США. 
Таблиця 3. Прямі іноземні інвестиції в сектори економіки України, млн. доларів США

\begin{tabular}{|c|c|c|c|c|c|c|c|}
\hline Сектор економіки & 2012 & 2013 & 2014 & 2015 & 2016 & 2017 & 2018 \\
\hline Сільське, лісове та рибне господарство & 725,3 & 717,8 & 776,9 & 617,0 & 502,2 & 586,2 & 578,6 \\
\hline Промисловість & 17303,8 & 18031,1 & 17681,4 & 12419,4 & 9893,6 & 9667,6 & 10543,7 \\
\hline Переробна промисловість & 12394,2 & 12899,3 & 12004,6 & 8797,6 & 7531,9 & 7523,9 & 7999,9 \\
\hline Металургійне виробництво & 5585,2 & 5175,3 & 3354,6 & 2181,3 & 1533,1 & 1560,8 & 1637,1 \\
\hline Фінансова та страхова діяльність & 12908,1 & 13094,9 & 12261.4 & 6421,7 & 4350,1 & 3627,4 & 3526,3 \\
\hline Операції з нерухомим майном & 3508,9 & 3878,3 & 4768,3 & 3979,4 & 3882,1 & 3764,4 & 3796,3 \\
\hline Всього інвестицій & 48197,6 & 51705,3 & 53704,0 & 38356,8 & 32122,5 & 31230,3 & 31606,4 \\
\hline
\end{tabular}

Джерело: [15]

Зростаючий світовий попит на сільськогосподарську продукцію слід використовувати як стимул для інвестицій та інноваційного розвитку сільського господарства в Україні. Посилення економіки та її конкурентних переваг на світових ринках сприятиме оптимізації функціонування сільськогосподарських підприємств України.

В останні роки метою сільського господарства країни було збільшення обсягів виробництва. Масштабне зростання сільськогосподарської продукції спрямоване насамперед на постачання внутрішнього ринку достатньою кількістю продовольства. Він повинен бути орієнтований на забезпечення споживання науково обгрунтованих стандартів основних харчових продуктів за вигідними цінами, а також на реалізацію значної кількості продовольчих товарів на зовнішніх ринках, де попит на сільськогосподарську продукцію, особливо на зерно, постійно зростає.

Результати діяльності сільськогосподарських підприємств безпосередньо залежать від стану їх основних фондів, значна частина яких використовується на придбання та реконструкцію існуючих об'єктів. Інвестиції слід використовувати насамперед для розвитку матеріально-технічної бази сільськогосподарських підприємств, оскільки їх основні засоби мають тенденцію до зносу, а термін їх використання у багатьох сільськогосподарських підприємствах перевищує 15 років, а їх кількість постійно зменшується. Тому необхідно спрямовувати капітальні вкладення на оновлення парку тракторів та комбайнів.

При недостатній кількості тракторів, комбайнів та сільськогосподарських машин сільськогосподарські підприємства доводиться купувати їх за кордоном, але, як правило, вони не нові, але вже використовуються, що знижує їх ціни. Власне виробництво сільськогосподарської техніки в Україні збільшується з кожним роком.

Таблиця 4. Виробництво тракторів, комбайнів та сільськогосподарської техніки в Україні в 2013 - 2017 роках, тис.шт

\begin{tabular}{|l|l|l|l|l|l|}
\hline \multicolumn{1}{|c|}{ Тип техніки } & \multicolumn{1}{c|}{2013} & 2014 & 2015 & 2016 & 2017 \\
\hline Трактори & 2,9 & 2,7 & 2,8 & 3,3 & 4,0 \\
\hline Розпушувачі та культиватори & 4,4 & 3,7 & 3,4 & 3,8 & 4,0 \\
\hline Дискові борони & 2,0 & 2,0 & 2,3 & 2,8 & 3,3 \\
\hline Борони (крім дискових) & 7,8 & 7,9 & 5,8 & 8,7 & 7,3 \\
\hline Сівалки & 5,6 & 4,4 & 4,2 & 4,8 & 5,1 \\
\hline Зернозбиральні комбайни & 68 & $\ldots{ }^{*}$ & 100 & 154 & 70 \\
\hline
\end{tabular}

*Дані не оприлюднюються з метою забезпечення виконання вимог Закону України «Про державну статистику» щодо конфіденційності статистичної інформації.

Джерело: [16]

Як наслідок, економіка України перестає нести збитки та стає більше незалежною від економік інших країн. Також важливо стимулювати сільськогосподарські підприємства в закупівлі такого обладнання. Це, безумовно, зменшить витрати на виробництво продукції рослинництва та створить більше робочих місць у секторі, що стимулює розвиток економіки країни.

Без адекватного забезпечення технічними ресурсами вести успішний бізнес у аграрній сфрері неможливо. Тому придбання обладнання та техніки - це дорога, але необхідна частина обробітку землі. За даними Департаменту інженернотехнічного забезпечення та сільськогосподарського машинобудування Міністерства сільського господарства України, мі-

німальне щорічне оновлення парку тракторів та сільськогосподарської техніки для задоволення технологічних потреб аграрного сектора оцінюється у 35 млрд. грн., у тому числі близько 40 тис. одиниць тракторів (15 млрд. дол. США) та майже 7 тис. зернозбиральних комбайнів (10,5 млрд. дол. США доларів). Парк машин та тракторів морально та технічно зношений, і його нинішнє забезпечення становить лише 60-65 відсотків технологічних потреб. Експлуатація застарілої техніки призводить до частих простоїв через ремонт та налагодження. Отже, це призводить до затримок сезонних польових робіт, порушень технологічних вимог до сільськогосподарських культур, що негативно позначається на якості врожаю та збільшує втрати.

Таблиця 5. Порівняльна таблиця закупівель сільськогосподарської техніки у 2017 і 2018 роках.

\begin{tabular}{|c|c|c|c|c|c|c|}
\hline \multirow{3}{*}{ Найменування } & \multicolumn{2}{|c|}{2017} & \multicolumn{2}{|c|}{2018} & \multirow{2}{*}{\multicolumn{2}{|c|}{ Відхилення 2018 до 2017 рр. }} \\
\hline & \multirow[b]{2}{*}{ кількість шт. } & \multirow{2}{*}{$\begin{array}{c}\text { середня ціна, грн } \\
\text { за шт }\end{array}$} & \multirow[b]{2}{*}{ кількість шт. } & \multirow{2}{*}{$\begin{array}{c}\text { середня ціна, } \\
\text { грн за шт }\end{array}$} & & \\
\hline & & & & & кількість, шт & $\begin{array}{c}\text { середня ціна, } \\
\text { тис.грн }\end{array}$ \\
\hline Трактори всіх видів & 3688 & 2013,2 & 3105 & 2007,7 & -583 & $-5,5$ \\
\hline Культиватори & 2374 & 460,2 & 1828 & 478,5 & -546 & $+18,3$ \\
\hline Борони & 2740 & 429,6 & 2505 & 388,8 & -235 & $-40,8$ \\
\hline Сівалки (без тукових) & 2322 & 1312,5 & 1718 & 1621,9 & -604 & $+309,4$ \\
\hline Зернозбиральні комбайни & 1026 & 4444,4 & 576 & 5074,1 & -450 & $+629,7$ \\
\hline
\end{tabular}
Джерело: [17; 18] 
Як видно з таблиці, сільськогосподарські підприємства мають менше ресурсів для придбання техніки. Середня ціна за техніку збільшується, а в свою чергу кількість купленої техніки зменшується інколи у два рази. Це можна пояснити зниженням купівельної спроможності підприємств та зростанням цін на цей вид обладнання з урахуванням валютних курсів на момент придбання. Наприклад, якщо у 2011 році курс долара до гривні становив 8 гривень за 1 долар США, у 2019 році курс зростав до 27 гривень за 1 долар США.

Інвестиції в технічне забезпечення рослинництва $€$ необхідними та привабливими. По-перше, як основа вирощування рослин зернові та олійні культури завжди користуються попитом на внутрішньому та зовнішньому ринках. По-друге, обсяги інвестицій є помірними порівняно з іншими інвестиціями в сільське господарство. На початку достатньо вкладати у галузь в середньому від 1 до 2 тис. доларів США за 1 га. Середній термін окупності інвестицій становить 2-4 роки.

$€$ деякі ризики, які перешкоджають інвестиціям у рослинництво. Переважно це стосується можливого втручання уряду в регулювання експорту. Такі дії можуть призвести до зниження цін на внутрішньому ринку та ускладнити реалізацію сільськогосподарської продукції.

Крім того, існують ризики, які залежать від державного регулювання ринку землі в Україні. Уряд планує зняти мораторій на продаж земель сільськогосподарського призначення до 1 грудня 2019 року, відсутність ефективної законодавчої бази та узгоджених дій інститутів галузі сприймаються інвесторами як додаткові ризики.

Ситуація, що склалася на ринку обладнання для сільського господарства, з одного боку, була викликана зростаючим попитом на нову економічну та високопродуктивну сільськогосподарську техніку внаслідок сприятливих високих уро- жаїв сільськогосподарської продукції, що зробило це можливим для фермерів відновити свій парк застарілих машин та тракторів, а з іншого боку - значного зростання їх цін через коливання національної валюти та введення нових правил щодо ввізного мита.

За цих умов держава не повинна залишатися спокійним спостерігачем. У сучасній складній економічній ситуації в країні важливим заходом підтримки ринку сільськогосподарської техніки має стати чітка державна політика щодо стимулювання оновлення технічного обладнання. Це може статися через механізм пільгових позик, розвиток лізингу та компенсації видатків, що має сприяти розвитку матеріально-технічної бази, всебічній механізації та автоматизації технологічних процесів, збереженню родючості ґрунтів у сільського господарства на основі найкращого машинобудування як вітчизняних, так і зарубіжних виробників (Огляд ринку техніки для АПК). Тому для стимулювання інвестицій важливо сформувати якісно нову політику, спрямовану на підвищення інвестиційної привабливості сільського господарства

Висновки. Інвестиції в сільськогосподарські підприємства $є$ основою для впровадження сучасних технологій виробництва та переробки продукції рослинництва та тваринництва. В останні роки обсяги інвестицій для вирішення проблем сільського господарства були недостатніми, проте можливості їх зростання залежать не лише від стану сільського господарства, але і від загального інвестиційного середовища - макроекономічної стабільності в країні, боротьби з корупцією тощо. захист прав інвесторів. Зі свого боку, держава повинна сформувати активну інвестиційну політику, яка стимулюватиме інвестиційні процеси шляхом створення сприятливого інвестиційного клімату. Зростання інвестицій, в свою чергу, забезпечить інновації в конкурентному виробництві.

\section{Список літератури:}

1. Libor Krkoska, "Foreign direct investment financing of capital formation in central and eastern Europe",London: European Bank for Reconstruction and Development, Working paper No. 67, (2001) Харків, 17

2. Гуткевич С. О., Пугачов М.І., Завадських Г.М., Занозовська О.Г. (2016). Стратегія розвитку: інвестиційний вимір.

3. Захарчук О. В. Проблеми матеріально-технічного забезпечення сільськогосподарських підприємств України / О. В. Захарчук // Економіка АПК / О. В. Захарчук., 2014. - № 7. - С. 92-99.

4. Кисіль М. І. Сучасні виклики, стратегічні пріоритети та завдання щодо інвестиційного забезпечення розвитку сільського господарства / М. І. Кисіль // Інноваційна економіка / М. І. Кисіль., 2014. - С. 14-19.

5. Коденська М. Ю. Інвестиційна складова аграрно-промислової інтеграції / М. Ю. Коденська, Ю. О. Нестерчук // Економіка АПК / М. Ю. Коденська, Ю. О. Нестерчук., 2011. - С. 45-51.

6. Гераймович В. Л. Інвестиційний процес та його вплив на розвиток аграрного сектору / В. Л. Гераймович. - Житомир, 2014. -20 c.

7. Лупенко Ю. О. Стратегічні напрями розвитку сільського господарства України на період до 2020 року / Ю. О. Лупенко, В. Я. Месель-Веселяка. - Київ: Національний науковий центр „Інститут аграрної економіки”, 2012. - 182 с.

8. Ратошнюк Т. М. Інвестиційна привабливість аграрної сфери / Т. М. Ратошнюк, М. А. Мартинюк // Вісник Сумського національного аграрного університету. Фінанси і кредит / Т. М. Ратошнюк, М. А. Мартинюк., 2013. - С. 88-93.

9. Левченко Н. В. Методи оцінювання інвестиційної привабливості сільського господарства регіонів України в контексті стратегічного планування / Н. В. Левченко, В. В. Огліх. // Актуальні проблеми економіки. - 2012. - №8. - С. 285-293.

10. Інвестиційна привабливість сільськогосподарських підприємств України / О. М. Вишневська, О. А. Філатова // Економічний простір. - 2013. - № 72. - С. 25-34. - Режим доступу: http://nbuv.gov.ua/UJRN/ecpros 2013725

11. Готра В. В. Сучасний стан, фактори забезпечення та напрями активізації інвестиційної діяльності у сфері сільського господарства / В. В. Готра // Актуальні проблеми економіки / В. В. Готра., 2015. - С. 114-121.

12. Ліссітса А. Україна зацікавлена в довгострокових інвестиціях у сільське господарство [Електронний ресурс] / Алекс Ліссітса // Урядовий кур'єр. - 2011. - Режим доступу до ресурсу:https://ukurier.gov.ua/uk/articles/ukrayina-zacikavlena-vdovgostrokovihinvesticiyah/.

13. Гуткевич С. О. Формування інвестиційної привабливості аграрного сектора економіки. / С. О. Гуткевич., 2004. - 31 с. 
14. Інноваційна діяльність в аграрній сфері: інституціональний аспект [Текст] : монографія / Саблук П. Т. [та ін.] ; ННЦ "Ін-т аграр. економіки". - К. : ННЦ ІАЕ, 2010. - 704 с.

15. Статистичний збірник «Прямі інвестиції (акціонерний капітал) в економіці України/з України: за країнами світу; країнами ЄС; видами економічної діяльності; по регіонах (2010-2018)» [Електронний ресурс] - Режим доступу до ресурсу: https://ukrstat.org/uk/operativ/operativ2018/zd/inv_zd/pi_ak_ks_reg_kv/pi_ak_ks_reg_kv_u/arh_pi_ak_ksvr_u.html.

16. Статистичний збірник 2017 [Електронний ресурс]. - 2018 - Режим доступу до ресурсу: https://ukrstat.org/uk/druk/publicat/kat_u/publ1_u.htm.

17. Придбання підприємствами матеріально-технічних ресурсів для виробничих потреб за 2017 рік [Електронний ресурс]. - 2018. - Режим доступу до ресурсу: https://ukrstat.org/uk/operativ/operativ2018/sg/pr_mt_res/arh_pr_mt_res_u.htm.

18. Придбання підприємствами матеріально-технічних ресурсів для виробничих потреб за 2018 рік [Електронний ресурс]. - 2019. - Режим доступу до ресурсу: https://ukrstat.org/uk/operativ/operativ2018/sg/pr_mt_res/arh_pr_mt_res_u.htm.

Nazarenko D.V., undergraduate, Sumy National Agrarian University (Sumy, Ukraine)

\section{ANALYSIS OF THE INVESTMENT ATTRACTIVENESS OF AGRICULTURAL ENTERPRISES OF UKRAINE}

The article considers the current state and features of the development of investment attractiveness of agricultural enterprises of Ukraine. The analysis of foreign investments into the economy and agro-industrial complex of Ukraine is carried out. The main problems of investment support of agricultural enterprises are revealed. problems.

Keywords: investments, investment attractiveness, agribusiness development, investment activity, agribusiness development

Дата надходження до редакції: 02.02.2019 р. 